\title{
Experience of parents of children with congenital heart disease: feelings and obstacles
}

\author{
Vivência de pais de crianças com cardiopatia congênita: sentimentos e obstáculos
}

Thaís Sena Mombach Barreto ${ }^{1}$, Victória Tiyoko Moraes Sakamoto ${ }^{1}$, Jardel Scremin Magagnin ${ }^{1}$, Débora Fernandes Coelho $^{1}$, Roberta Waterkemper ${ }^{1}$, Simone Travi Canabarro ${ }^{1}$

Objective: understand the meaning of the experiences of parents of children with congenital heart disease regarding feelings, obstacles and expectations. Methods: qualitative study conducted at a pediatric intensive care unit of a reference hospital. Participants corresponded to seven mothers and four fathers of children with congenital heart defect, surgically corrected and with more than 8 hours of admission, totalling 11 participants. Data collection was performed through semi-structured individual recorded interviews. Data were described according to thematic content analysis. Results: five thematic categories emerged: (1) unpreparedness to face the problem; (2) feelings involved (3) factors that make difficult to face the problem; (4) factors that facilitate facing the problem; (5) spirituality. Conclusion: each family is unique and needs support to better face the disease and its process. It is essential to develop interdisciplinary network support, providing comprehensive care.

Descriptors: Heart Defects, Congenital; Child, Hospitalized; Congenital Abnormalities; Parents.

Objetivo: compreender o significado das vivências de pais de crianças com cardiopatia congênita com relação a sentimentos, obstáculos e expectativas. Métodos: estudo qualitativo realizado em unidade de terapia intensiva pediátrica de hospital de referência. Participaram sete mães e quatro pais de crianças com cardiopatia congênita corrigida cirurgicamente e com mais de 8 horas de internação, totalizando 11 participantes. Coleta de dados foi realizada por entrevista semiestruturada individual e gravada. Os dados foram descritos segundo análise de conteúdo do tipo temática. Resultados: foram construídas cinco categorias temáticas: (1) despreparo para o enfrentamento; (2) sentimentos envolvidos (3) fatores que dificultam o enfrentamento; (4) fatores que facilitam o enfrentamento; (5) espiritualidade. Conclusão: cada família é única e necessita de apoio para melhor enfrentamento frente à doença e seu processo. É essencial desenvolver rede de suporte interdisciplinar, proporcionando assistência integral.

Descritores: Cardiopatias Congênitas; Criança Hospitalizada; Anormalidades Congênitas; Pais.

$\overline{{ }^{1} \text { Universidade Federal de }}$ Ciências da Saúde de Porto Alegre. Porto Alegre, RS, Brazil.

Corresponding author: Simone Travi Canabarro

Rua Sarmento Leite, 245, Centro , Histórico CEP: 90050-170. Porto Alegre, RS, Brazil. E-mail : simonet@ufcspa.edu.br 


\section{Introduction}

Congenital heart disease and other diseases that affect children represent an stressful and destabilizing factor, especially for the family. Most often, such diseases are diagnosed early in life and this may be a positive factor because it enables rapid intervention and consequently better prognosis, but at the same time, it can a negative factor in the sense that hinders the child's bond with the family. In this context, a balanced articulation between the physical and mental aspects, shaken by the diagnosis and therapeutic interventions, is necessary.

Congenital heart disease has high incidence among the congenital malformations, with variable prevalence depending on the population studied, without much divergence of values. Prevalence of congenital heart diseases ${ }^{(1)}$ was identified in 9.58: 1,000 live births between 1990 and 2003 in the state of Minas Gerais, Brazil. In Brazil, congenital abnormalities are the second cause of mortality in children under 1 year of age ${ }^{(1)}$.

Cardiovascular malformations have multifactorial etiology but there is clear highly relevant environmental and genetic influence. Among such influent factors are maternal rubella, malnutrition, maternal diabetes, maternal age over 40 years, the use of teratogens and radiation. Among genetic factors, the most common are the chromosomic factors (Turner syndrome, Cri Du Chat syndrome, Down syndrome), mutant genes (mucopolysaccharidosis, neurofibromatosis, among others) and family history of congenital heart disease $\mathrm{e}^{(2-3)}$.

Besides all the pathophysiological and epidemiological factors, it is extremely important to emphasize that the disease has repercussions not only in the child's life but also in the ones responsible for them, causing great anxiety. Parents build a picture, according to their beliefs and interpretations, of their child and its development process, its illness and health and even a picture of themselves as educators or as persons able to confront problematic situations ${ }^{(4)}$. Feelings of helplessness of the mother and mourning the loss of the idealized child may give rise to a feeling of great concern for the real child, often resulting in an exaggerated concern with the child's condition. Ideally, this family should provide safety and good care conditions for the development of the child. In this context, it is essential to support health professionals in the orientation of care, since this is decisive for greater confidence of parents in coping with the disease.

The theme of the present research emerged from the work and experiences of the authors, as a reflection on the needs of parents of children with congenital heart disease. Therefore, an attempt was made to cover the perception of these parents about the disease, its difficulties, the impact of the disease on the family's quality of life and a picture of the link between these parents (and other relatives) and their children in front of the large number of interventions and operations that must be performed.

When performing search for scientific and reference articles, a progressive increase in the number of studies that address congenital heart disease was found. There is, however, still a limited number of studies on psychological aspects in this context, emphasizing the parent's need for more guidance and support from health professionals, since most studies prioritize quantitative analysis ${ }^{(5)}$. This study is, therefore, a source of knowledge for health professionals and academics so that they become aware of the main needs of parents and thus offer the best possible support to these families.

In this light, the following concern emerged: What is the meaning assigned by mothers and fathers in the facing the congenital heart disease of their children? Because of this concern associated with the constant need to improve the care of children who experience the admission to the Pediatric Intensive Care Unit due to congenital heart disease and their families, the present study aimed to understand the 
meaning of the experiences of parents of children with congenital heart disease.

\section{Methods}

This was a qualitative research, it was held in the Pediatric Intensive Care Unit of a regional and national reference hospital in the diagnosis and treatment of pediatric diseases, especially highly complex diseases, with patients of cardiology as the most prevalent, of the capital city of Rio Grande do Sul State, South region of Brazil. Participants corresponded to seven mothers (63.6\%) and four fathers $(33.3 \%)$ of children with congenital heart defect surgically corrected and with more than 8 hours of admission, totalling 11 participants. Participants were selected based on convenience. Inclusion criteria were: be a mother and/or father aged over 18 years, with respective child hospitalized for at least 8 hours after surgery (time required for physiological child's stabilization and decrease of family anxiety), with availability to participate in the research and sign the Instrument of Informed Consent. Data collection was carried out between June and July 2012 through semistructured interviews with identification data and guiding questions, seeking to reach the objective of the study. Interviews were held in a private place and lasted around one hour, with variability of 30 minutes. Audio were recorded to facilitate the communication between interviewer and the interviewed person and, afterwards, these were transcribed in full-length. Data collection terminated upon occurrence of data saturation ${ }^{(6)}$.

The process of data analysis was guided by the proposal of content analysis, thematic type, which "consists in discovering the units of meaning that make up a communication, whose presence or frequency mean something to the targeted analytical object" (7:315-8). Operationally, it unfolds in three stages: (1) Pre-analysis, in which the overview of all the communications is done, the corpus constitution, with material necessarily meeting the qualitative validity standards as completeness, representativeness and homogeneity. Formulation and reformulation of hypotheses and objectives can also be carried out in this step. Registration units, context units, clippings, the form of categorization, the type of coding and the more general theoretical concepts that guide the analysis are determined; (2) Material exploration aims to classify the content in order to achieve the core understanding of the text coming up into categories that are expressions and words that constitute meaning to what is sought in the text; (3) Treatment of obtained results and interpretation, in which the lines were subjected to interpretation that highlighted the information obtained in accordance with the purpose of the study. All ethical precepts to protect the human subject research were followed and, therefore, anonymity was guaranteed by suppressing and encoding participants' names. Thus, participants were identified by the letter " $R$ " (Respondent) in high capital followed by sequence number : $1,2,3, \ldots, 11$, according to the order of participation in the research. The study complied with the formal requirements contained in the national and international regulatory standards for research involving human beings.

\section{Results}

The age of respondents ranged from 18 through 54 years with average of $30.5 \pm 13.54$ years. The level of education ranged from 5 th year of elementary school to higher education. The average time of schooling was approximately 9.9 years. The analysis found $91.0 \%$ (10) of respondents as having a religion, $63.6 \%$ (7) of which were Catholic. As regards the origin, the major part of the sample, $63.6 \%$ (7), did not come from Porto Alegre. One respondent was foreigner. With regard to children, ages ranged from 15 days through one year and three months, with average of 5.42 months, and only one child did not have prenatal care during pregnancy.

The process of thematic analysis enabled the 
construction of five categories: 1) The unpreparedness to face the process of disease and the possibility of loss; 2) feelings involving care; 3) factors that hinder the confrontation of the disease and providing care; 4) factors that facilitate the confrontation of the disease and providing care; 5) spirituality as an imperative factor in facing the process of disease.

In the first category regarding the unpreparedness to face the process of disease and the possibility of loss, it is clear that parents feel desperate when they experience the processes of development of a disease, the congenital heart disease, in their baby child. Desperation was the reaction more frequently expressed during the discovery of the disease. At the beginning when I came here, I was desperate; he came here in a very serious state, now I'm less stressed (R11). At that moment we got like (break) we could not explain, because no one in the whole family has such a problem, from both sides have, no one had had problems of malformation in the heart. At that moment we got like, kind of, surprised, but everyone held hands and we faced it (R8).

Before the situation of illness, depending on parents' level of preparation in relation to the death and the dying process, denial can be presented as a defensive mechanism. Denial process can be triggered in the case of parents of children with serious disease that can lead to death, such as congenital heart disease. However, among all parents surveyed, only one showed such a feeling. Actually, I did not believe. I only believe it when he was born and they did not bring my boy back to me, they took him to the intensive care unit. Then I realized that he had something serious (R5).

In the second category, related to feelings involving the care, from diagnosis to treatment, were observed: anxiety, fear, guilt, hopelessness, helplessness and insecurity. Upon receiving the diagnosis of congenital heart disease, study participants reported surprise, either at birth or with the child in older age. I never imagined that I would go through this. Neither I nor his father, nor anyone .... That he would be like this, because he was normal, he use to do everything, he used to play, and he almost died. I almost lost him (R4). Parents become anxious and frightened while the situation is experienced. Then, that fear hits on us, that anxiety again (R2). My biggest fear is that he feelS bad, something like that, and I don't know what to do, if it's something you have to do fast (R6).

Anxiety and fear are feelings that come from the moment when parents begin "to realize" the problem, realizing the real situation to be confronted. The manifestations are uncertainty about the future of the child and the search for causes, which include the very actions of parents and the time to diagnosis. And, when they sometimes say it's my fault, that it may be because I'm HIV positive, I feel guilty. Sometimes I feel guilty because of that little problem of the eye that he has, he has glaucoma in the eye. I feel guilty (R5). They did the echocardiographic and found that he had been born with problems in the arteries. The only thing is that this surgery, the child has to do it in less than a month, to be in time, but my child was too old to make that heart surgery, he is already one year old, exactly one year (R4).

Parents reveal feelings of hopelessness, which has been linked to impotence and insecurity, when faced with this situation of prolonged suffering. This is revealed in the statements by the desire to escape from reality and the possibility of performing new surgeries. It's just that, it turned out that he had several problems that he could be born and die right after. I thought that by doing the surgery he would be able to overcome, then he would start to gain weight and have a more or less normal life (R6). He underwent a surgery when he had five days of life. Wednesday he took the CHANT off, and now he did the BLEM. But, perhaps now he may need another surgery, there when he turns five, six years old, he will have to make other one (R2).

In the third category, where factors that hinder the confrontation of disease and providing care were leased, are found the factors of the case when the child is the first child, the need for reorganization of family and financial routines. Being our first child is already difficult, and when it comes with a little problem, it is even more so. (R4). My only concern is my wife. She's home, there is also the other kiddos. She called this morning, he had a little cold. She takes him to the hospital and has the consultation, because I can not do anything here (R1). The question is, what has changed is that financial part, as we are not from here, there is a lot of much greater expense. Her father can not go to Torres because of lack of money (R10). It was also 
possible to identify the lack of professional support in the accounts of participants, as another factor that hinders the confrontation of the disease process of the child. Some parents expressed the difficulty of facing the diagnosis and attributed it to the feeling of lack of support from professionals throughout hospitalization. It's being harder here. Too many children for too few nurses here ... they are crying, we call the nurse, the nurse delays to come, I understand their side, there are many children, they have to assist a child that is in more serious situation than mine. Sometimes I understand, but it's hard. Sometimes they are talking and I'm calling and they delay to come (R2).

In the fourth category, where the factors that facilitate the confrontation of the disease and providing care are defined, was evident that the support received was an important factor in coping with the child's hospitalization in the case of families who could feel the care of members of the multidisciplinary team working in the Pediatric Intensive Care Unit. We also had good base with the psychologist (R9). The professionals here are good and attentive, I have nothing to complain, I am being well assisted (R1). I have nothing to complain about it. Every time that I ask my questions, they answer all my doubts, about the surgery, the postsurgery (R2).

The spirituality of parents as an imperative factor in facing the process of becoming ill, referring to the fifth category, proved to be another factor that contributes significantly to confronting the disease process, such as the experience of congenital heart disease of a child. Demonstrations of spirituality by the parents in this study were faith in healing and/or improving and the possibility of returning to a healthy life. I hope him to grow healthy, if it another becomes necessary, then, that may everything go all right, that he grows well without complications (R2). That he become a normal child. And even with this problem, that he may be able to do everything (R3). It is now, I think he recovers. God is with him (R8). You have to have faith (R5).

\section{Discussion}

It is understandable that having a child with a disease that can lead to death represents a despairing situation for the father and/or mother. Parents do not expect the child fall ill, let alone the possibility of dying. This reaction is seen in other contexts carried out with the same population, mainly parents in process of parenthood, that is, in the initial process of subjective experience of parental roles ${ }^{(5)}$. Intense feelings of helplessness and fear are triggered in the parents from the moment of diagnosis of congenital heart disease due to the possibility of death of their children $^{(5)}$.

When the diagnosis is set immediately after birth, mothers demonstrate unpreparedness to face it, as well as to prepare for possible grieving process. Early diagnosis allows parents to prepare for this moment, especially when it occurs during pregnancy ${ }^{(5)}$. The information that the child has a "problem" after birth may represent the beginning of a path of suffering for the family, as well as coping with the process of being born-falling ill, and that is why the surprise $\mathrm{e}^{(8)}$.

At the same time, it demonstrates the difficulty of parents of experiencing the disease of the child that can bring death as a consequence. Parents never expect a child to develop an illness. Thus, receiving such news becomes something unexpected and frightening. The feeling is described as "fall", "run out of ground," "feel the world collapse," causing a state of fear and panic, despair, unbearable pain and suffering, not only in the case of parents but the whole family ${ }^{(8-10)}$. These are feelings that involve the moment of awareness of the existence of the problem and the need to search for treatment alternatives.

Guilt is, most of the times, a feeling that hits the mother only, because she was the one who gave birth. Throughout this experience, mothers start to recall previous experiences in details, hoping to find the cause for so much suffering. It may also manifest itself in both the father and mother, influencing directly on their roles ${ }^{(8)}$.

Generally, parents live a moment of emotional instability, something not expected. There is a challenge: facing the problem, with an initial feeling 
of fear ${ }^{(10)}$. Parents, by knowing the risks that the child runs from that moment and experiencing the same situation with other parents and children, have fear of losing their child and, therefore, they experience a distressing wait. This anguish of existence is that allows the human being the moment of selfconsciousness in the world and allows to immerse in the alternatives that can bring pain and not only pleasure and happiness ${ }^{(8)}$. It is for this perceived attitude that, in the majority cases of watching a child to fall ill, parents want and expect to have the child within the standards of normality.

Since there is no permanent cure for sure, these feelings stuck in parents. While this confirmation does not take place, the distress and suffering are not diluted, contributing to the feeling of helplessness, distrust and disbelief. Even before the first attempt to cure - the surgery -, fear of losing the child and the possibility of facing new surgeries brings parents at risk of reliving the pain, aggravating the socioeconomic and cultural issues ${ }^{(11)}$.

Parents of children with congenital heart disease tend to have more stress than parents of children with other disorders. Dilemmas of normality and social integration are part of this scenario. In a study conducted about the quality of life of parents of children with heart disease, the emotional role and mental health are among the factors that interfere in this matter ${ }^{(12)}$.

In addition to the outcrop of feelings, the process of becoming ill brings loneliness to parents in the hospitalization process of the child. This situation does not relieve the mother's concern for children who are estranged, and her husband, caregiver at admission, in relation to his wife and care for the other children who remain at home.

The child with congenital heart disease needs special care actions, both in hospitalization and at home. Such care can contribute to social isolation of parents, fear of removal and triggering a crisis in the child, as well as the impossibility of immediate relief. This constant feeling can make parents caregivers responsible for the direct care, thus reducing the social support network ${ }^{(11)}$. Such an attitude is assumed as a strategy to overprotect the child from cardiac problems and impose limitations in order to avoid destabilization of the child's clinical condition. They try to keep the children without crying or even without showing any expression. The search for tranquillity to keep the child out of the crisis is inherent to parents.

There is a need for family restructuring, because the removal of a genitor from home is an event that changes the whole structure and dynamics of the family about the roles and links established the close relationship between its members ${ }^{(13)}$.

Financial instability was one of the most representative factors as a problem of coping with the process of disease of a child with heart disease. Most of participant families of this study did not have enough economic conditions to keep up with the demands of treatment in hospital. It became clear that financial conditions have a great impact on the quality of life of parents of children with this disease and this finding is corroborated by other authors ${ }^{(12)}$.

This shows that the daily lives of these families is changed due to the demands of hospitalization, such as the displacement and feeding, setting extra expenditures to the family routine. This situation is aggravated when the parents do not live geographically close to the hospital ${ }^{(11)}$.

The support to the family is an imperative professional attitude toward children and their parents. The establishment of a supportive relationship contributes to the alleviation of suffering before the disease, and this may come through continuous sharing of pain and responsibilities, transmitting care, strength and hope to the subjects ${ }^{(10)}$. However, it was observed that some participants do not receive proper support and feel neglected, that is, not well assisted. The need for and the appreciation of the comprehensive follow-up of these children cannot be expressed because they may relate to as much the family, by its own peculiarities, needs this attention ${ }^{(14)}$. It is the desire of parents to see their 
children receive care from a competent team, and this demonstrates the important role of the nursing care to the cardiac child. Furthermore, parents long to understand the treatment the child is undergoing and they long have the opportunity to receive support from professionals. It is known that the proper functioning of partnership between the team and the child's family is a valuable resource for parents on the coping process $^{(15)}$.

The effective strategy to implement a program of intensive care for children with heart disease should include: multidisciplinary collaboration and involvement between pediatric cardiology, anesthesia, cardiac surgery, as well as many other subspecialties; a strategy of classification to quantify the transoperative risk; individual approach to the patient and anticipate care of possible complications ${ }^{(16)}$. Nurses must be aware of the needs of patients in the postoperative period of a cardiac surgery so that he/ she may identify the difficulties of this care and thus propose coping strategies ${ }^{(17)}$.

Spirituality is a multidimensional concept of religiosity. This influences the physical and psychological health of human beings, especially regarding the effects of stress on physical health. It may be understood as the search of people for answers to important questions related to life and involves the sacred or transcendent, that is, an organized system of beliefs, practices, rituals and symbols, which are recovered and used in personal experiences of overcoming traumas ${ }^{(18-19)}$.

Although there are many factors that hinder the confrontation, there is a great facilitator that significantly contributes in the process of disease in the family. Notably, having a child with this problem means "to have faith" in the opinion of parents. Among all the feelings unveiled in this and other studies, faith is the force that drives and encourages parents to fight every day for their child's health. Thus, spiritual connection is an important factor for many parents. This contributes to cope with stressful experiences. There is the feeling that it is not possible to live without the child and, therefore, they should seek in faith, in God and in hope, the necessary support ${ }^{(8,20)}$.

These feelings associated with the desire for healthy living come from the belief that the child still needs to grow and develop. The expression of faith is part of the spirituality. To have faith means to hope, to believe in something as a safe haven, where parents can renew their strength. Faith gives meaning and support to human beings in the face of unexpected life situations.

\section{Final Considerations}

The heart has, in its symbolism, a lifedeath duality, with high assigned value. Therefore, development of maternal and paternal feelings before facing the diagnosis of congenital heart disease, something never experienced before, is something expected and deserves due attention of health professionals.

Surprise, distress, fear, guilt, hopelessness, helplessness and insecurity were the main feelings evidenced in this study. Among the factors that stand out as obstacles and, thus, make it difficult to face the problem for the parents, are the lack of social support, with identification of loneliness of parents due to the social isolation resulting from hospitalization. Another factor rarely discussed in other works and that had the highest representation as an obstacle was the financial destabilization due to the need to reorganize family routines.

Feelings such as anguish and fear are linked to expectations of uncertainty of the child's future. Also feelings of hopelessness related to the expectation of future surgeries. Spirituality was linked to expectations of improvement or child's healing.

The present study had the main limitation of being performed in only one reference center, what does not allow for generalization of data. Another limitation was the fact that the parents had difficulty of leaving the child's bed, out of concern for the situation of children. However, all invited parents 
agreed to participate.

Health professionals and especially the nursing staff are responsible for carrying out the care of these families and should provide quality and safety, as well as aim at promoting vital learning from parents and family, , along with the multidisciplinary team, thus promoting adequate support network. The development of a supportive network, preferably interdisciplinary, is essential for the factors highlighted here be mitigated. Therefore it is essential to provide comprehensive care with services that meet the real needs of parents seeking cooperation between health team, child and family.

\section{Collaborations}

Barreto TSM and Canabarro ST contributed to the study design, collection, analysis and writing of the article. Sakamoto VTM and Magagnin JS contributed to the collection, analysis and writing of the article. Coelho DF and Waterkemper R contributed to the analysis and writing of the article. All authors contributed to the critical review and approval of the version to be published.

\section{References}

1. Telles JAB, Schüler-Faccini L. Congenital defects in Rio Grande do Sul: ultrasonographic diagnosis by fetal morphologic study. Rev AMRIGS. 2010; 54(4):421-6.

2. Dioclécio CJ, Dennis ARB, Fabio AL. Tratado de pediatria. São Paulo : Manole; 2014.

3. Hockenberry MJ, Wilson DW. Fundamentos de enfermagem pediátrica. Rio de Janeiro: Elsevier; 2011.

4. Gomes AG, Piccinini CA. Malformações no bebê e maternidade, aspectos teóricos e clínicos. Psicol Clín. 2010; 22(1):15-38.

5. KruelCS, Lopes RCS. Transição para a parentalidade no contexto de cardiopatia congênita do bebê. Psic Teor Pesq. 2012; 28(1):35-43.
6. Fontanella BJB, Luchesi BM, Saidel MGB, Ricas J, Turato ER, Melo DG. Amostragem em pesquisas qualitativas: propostas de procedimentos para constatar saturação teórica. Cad Saúde Pública. 2011; 27(2):389-94.

7. Minayo MCS. O desafio do conhecimento: pesquisa qualitativa em saúde. 12ª ed. São Paulo: Hucitec; 2010. p. 315-8.

8. Solberg O, Dale MT, Holmstrom H, Eskedal LT, Landolt MA, Vollrath ME. Long-term syptoms of depression and anxiety in mothers or infants with congenital heart defects. J Pediatr Psychol. 2011; 36(2):179-87.

9. Salgado CL, Lamy ZC, Nina RVAH, Melo LA, Lamy FF, Nina VJS. A cirurgia cardíaca pediátrica sob o olhar dos pais: um estudo qualitativo. Rev Bras Cir Cardiovasc. 2011; 26(1):36-42.

10. Cantwell-Bartl AM, Tibballs J. Psychosocial experiences of parents of infants with hypoplastic left heart syndrome in the PICU. Pediatr Crit Care Med. 2013; 14(9):869-75.

11. Rempel GR, Harrison MJ, Williamson DL. Is 'treat your child normally' helpful advice for parents of survivors of treatment of hypoplasic left heart syndrome? Cardiol Young. 2009; 19(2):135-44.

12. Simões S, Pires A, Barroca A. Comportamento parental face à cardiopatia congénita. Rev Anal Psic. 2010; 4(28):619-30.

13. Bruce E, Lilja C, Sundin K. Mother's lived experiences of support when living with young children with congenital heart defects. J Spec Pediatr Nurs. 2014; 19(1):54-67.

14. Mughal AR, Sadiq M, Hyder SN, Qureshi AU, A Shah SS, Khan MA, et al. Socioeconomic status and impact of treatment on families of children with congenital heart disease. J Coll Physicians Surg Pak. 2011; 21(7):398-402.

15. Meeker TM. Pentalogy of cantrell: reviewing the syndrome with a case report and nursing implications. J Perinat Neonatal Nurs. 2009; 23(2):186-94.

16. Damas BGB, Ramos CA, Rezende MA. Necessidade de informação a pais de crianças portadoras de cardiopatia congênita. Rev Bras Crescimento Desenvolv Hum. 2009; 19(1):103-13. 
17. Lira, ALBC, Araujo WM, Souza NTC, Frazão CMFQ, Medeiros ABA. Mapeamento dos cuidados de enfermagem para pacientes em pós-operatório de cirurgia cardíaca. Rev Rene. 2012; 13(5):1171-81.

18. Koenig HG. Research on religion, spirituality, and mental health: a review. Can J Psychiatr. 2009; 54(5):283-91.
19. Stratta P1, Capanna C, Riccardi I, Perugi G, Toni C, Dell'Osso L, et al. Spirituality and Religiosity in the Aftermath of a Natural Catastrophe in Italy. J Relig Health. 2013; 52(3):1029-37.

20. Harvey KA, Kovalesky A, Woods RK, Loan LA. Experiences of mothers of infants with congenital heart disease before, during, and after complex cardiac surgery. Heart Lung. 2013; 42(6):399406. 